\title{
Metal Aminocarboxylate Coordination Polymers with Chain and Layered Structures
}

\author{
Meenakshi Dan and C. N. R. Rao*[a]
}

\begin{abstract}
The synthesis and structures of metal aminocarboxylates prepared in acidic, neutral, or alkaline media have been explored with the purpose of isolating coordination polymers with linear chain and two-dimensional layered structures. Metal glycinates of the formulae $\left[\mathrm{CoCl}_{2}\left(\mathrm{H}_{2} \mathrm{O}\right)_{2}\left(\mathrm{CO}_{2} \mathrm{CH}_{2} \mathrm{NH}_{3}\right)\right]$ (I), $\left[\mathrm{MnCl}_{2}\left(\mathrm{CO}_{2} \mathrm{CH}_{2} \mathrm{NH}_{3}\right)_{2}\right]$ (II), and $\left[\mathrm{Cd}_{3} \mathrm{Cl}_{6}\left(\mathrm{CO}_{2} \mathrm{CH}_{2} \mathrm{NH}_{3}\right)_{4}\right]$ (III) with onedimensional chain structures have been obtained by the reaction of the metal salts with glycine in an acidic medium under hydro/solvothermal conditions.
\end{abstract}

These chain compounds contain glycine in the zwitterionic form. 4-Aminobutyric acid transforms to a cyclic amide under such reaction conditions, and the amide forms a chain compound of the formula $\left[\mathrm{CdBr}_{2}\left(\mathrm{C}_{4} \mathrm{H}_{7} \mathrm{NO}\right)_{2}\right]$ (IV). Glycine in the zwitterionic form also forms a two-dimensional layered

Keywords: acidity $\cdot$ aminocarboxylates - coordination polymers . open-framework structures transition metals compound of the formula [Mn$\left.\left(\mathrm{H}_{2} \mathrm{O}\right)_{2}\left(\mathrm{CO}_{2} \mathrm{CH}_{2} \mathrm{NH}_{3}\right)_{2}\right] \mathrm{Br}_{2}(\mathbf{V})$. 6-Aminocaproic acid under alkaline conditions forms layered compounds with metals at room temperature, the metal being coordinated both by the amino nitrogen and the carboxyl oxygen atoms. Of the two layered compounds $\left[\mathrm{Cd}\left\{\mathrm{CO}_{2}\left(\mathrm{CH}_{2}\right)_{5} \mathrm{NH}_{2}\right\}_{2}\right] \cdot 2 \mathrm{H}_{2} \mathrm{O}$ (VI) and $\left[\mathrm{Cu}\left\{\mathrm{CO}_{2}\left(\mathrm{CH}_{2}\right)_{5} \mathrm{NH}_{2}\right\}_{2}\right] \cdot 2 \mathrm{H}_{2} \mathrm{O}$ (VII), the latter has voids in which water molecules reside.

\section{Introduction}

Organically templated open-framework metal silicates and phosphates have been widely reported in the literature. ${ }^{[1,2]}$ In the last few years, there have been several investigations of open-framework metal carboxylates of varying dimensionalities. ${ }^{[3]}$ We have been interested in examining the extended structures of coordination polymers of different dimensionalities formed by metal aminocarboxylates, as aminocarboxylic acids can bond to the metal atoms in different ways by making use of both the amino nitrogen and the carboxyl oxygen atoms, for coordination under neutral or alkaline conditions. There are a few reports in the literature of linear chain and layered metal glycinates prepared under

[a] M. Dan, Prof. Dr. C. N. R. Rao

Chemistry and Physics of Materials Unit and CSIR Centre

of Excellence in Chemistry

Jawaharlal Nehru Centre for Advanced Scientific Research

Jakkur P.O., Bangalore 560064 (India)

Fax: (+91) 80-2208-2766

E-mail: cnrrao@jncasr.ac.in

and

Solid State and Structural Chemistry Unit

Indian Institute of Science, Bangalore 560012 (India) neutral conditions in which both the carboxylate and the $\mathrm{NH}_{2}$ groups coordinate to the metal. ${ }^{[4]}$ Two-dimensional coordination polymers of heterometallic glycinates have been reported recently. ${ }^{[5]}$ Under acidic conditions, where glycine occurs in the zwitterionic form, coordination to the metal commonly occurs through the carboxylate group. Coordination compounds of glycine and other amino acids in the zwitterionic form are known. ${ }^{[6]}$ The zwitterionic form of 4aminobutyric acid is reported to form a paddle-wheel type of cluster with copper, which connects layers with a perovskite topology to form a compound with three-dimensional architecture. $^{[7]}$

We have carried out the hydrothermal synthesis of a few metal glycinates under acidic conditions to explore the onedimensional chain and two-dimensional layered structures formed by them. We have also carried out the reactions of metal ions with 4-aminobutyric acid and 6-aminocaproic acid at acidic and alkaline $\mathrm{pH}$ to examine the extended structures formed under these conditions. We have obtained three metal glycinates with linear chain structures formed by glycine in the zwitterionic form, in addition to a chain structure formed by 4-aminobutyric acid under acidic conditions. We have been able to obtain a two-dimensional layered structure formed by glycine in the zwitterionic form. Two layered structures formed by 6-aminocaproic acid 
under neutral conditions have been characterized, one of them possessing voids containing water molecules.

\section{Results and Discussion}

One-dimensional structures: We have isolated and characterized three metal glycinates- $\left[\mathrm{CoCl}_{2}\left(\mathrm{H}_{2} \mathrm{O}\right)_{2}\left(\mathrm{CO}_{2} \mathrm{CH}_{2} \mathrm{NH}_{3}\right)\right]$ (I), $\left[\mathrm{MnCl}_{2}\left(\mathrm{CO}_{2} \mathrm{CH}_{2} \mathrm{NH}_{3}\right)_{2}\right]$ (II), and $\left[\mathrm{Cd}_{3} \mathrm{Cl}_{6}\left(\mathrm{CO}_{2} \mathrm{CH}_{2} \mathrm{NH}_{3}\right)_{4}\right]$ (III) - with chain structures, in which glycine is in the zwitterionic form. The asymmetric unit of $\mathbf{I}$ contains nine nonhydrogen atoms. The cobalt atom is in an octahedral environment and is bonded to two bridging glycinate oxygen atoms, two chlorine atoms, and two water molecules in a cis fashion. The carboxylate end of the glycine molecule bridges the Co centers to form chains, as shown in Figure 1a, which are arranged parallel to each other forming layers parallel to the $a c$ plane of the unit cell. The layers are separated by half the unit-cell length along the $b$ axis. Multipoint $\mathrm{N}-$ $\mathrm{H} \ldots \mathrm{O}, \mathrm{N}-\mathrm{H} \cdots \mathrm{Cl}$, and $\mathrm{O}-\mathrm{H} \cdot . \mathrm{Cl}$ hydrogen bonding between the chains in the layer and across the layer stabilizes the structure. The $\mathrm{Co}^{-} \mathrm{O}$ and $\mathrm{Co}-\mathrm{Cl}$ bond lengths in $\mathbf{I}$ lie in the
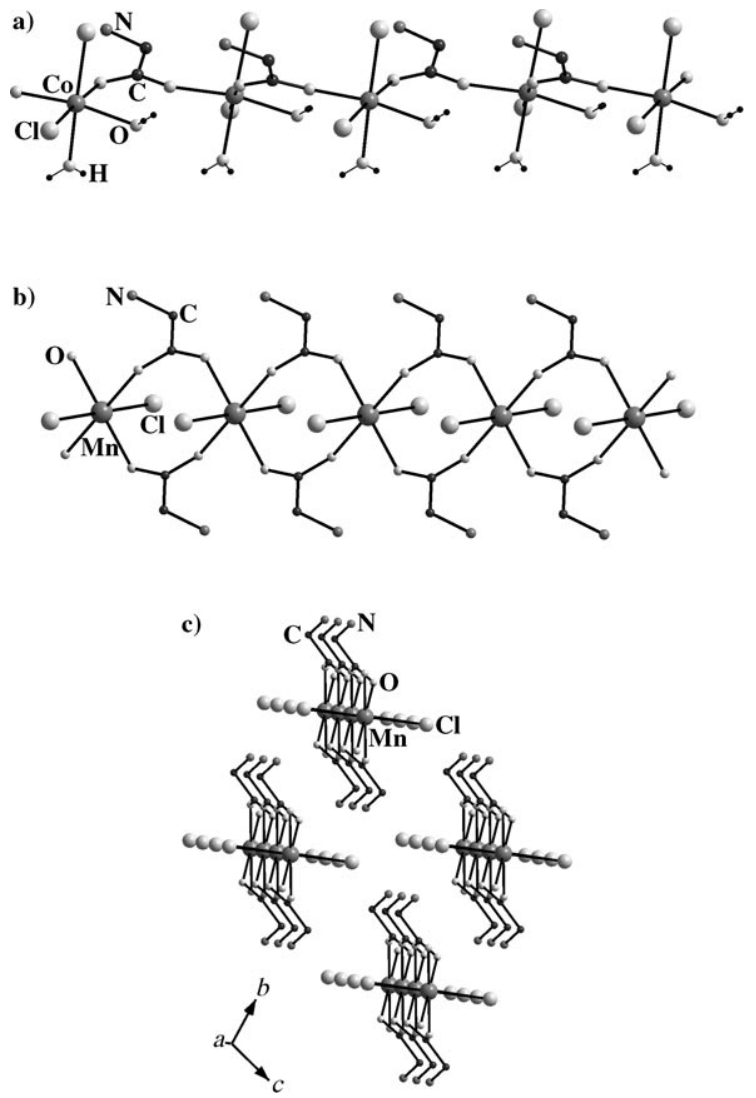

Figure 1. a) Chain structure of $\left[\mathrm{CoCl}_{2}\left(\mathrm{H}_{2} \mathrm{O}\right)_{2}\left(\mathrm{CO}_{2} \mathrm{CH}_{2} \mathrm{NH}_{3}\right)\right]$ (I) formed by the bridging of the Co centers by the glycine molecule. b) One-dimensional chain structure of $\left[\mathrm{MnCl}_{2}\left(\mathrm{CO}_{2} \mathrm{CH}_{2} \mathrm{NH}_{3}\right)_{2}\right]$ (II). Note the presence of two glycine bridges between the $\mathrm{Mn}$ centers compared with one bridge in I. c) Three-dimensional packing diagram of II. Hydrogen atoms of glycine are not shown. range of 2.074(2)-2.150(2) $\AA$ (average 2.106 $\AA$ ) and 2.399(1)-2.497(1) $\AA$ (average $2.448 \AA$ ), respectively. The average $\mathrm{C}-\mathrm{O}, \mathrm{C}-\mathrm{C}$, and $\mathrm{C}-\mathrm{N}$ distances of the glycine molecule are $1.257,1.508$, and $1.478 \AA$, respectively.

The asymmetric unit of $\left[\mathrm{MnCl}_{2}\left(\mathrm{CO}_{2} \mathrm{CH}_{2} \mathrm{NH}_{3}\right)_{2}\right]$ (II) contains seven non-hydrogen atoms with the $\mathrm{Mn}$ atom in a special position with half occupancy. The Mn atom is octahedrally surrounded by four oxygen atoms of bridging glycine molecules and two chlorine atoms in a cis fashion. As in $\mathbf{I}$, glycine is in the zwitterionic form bridging the metal centers through the carboxylate group, thereby forming chains parallel to the $a$ axis of the unit cell. The Mn centers in the chain are connected by two glycine bridges (Figure 1b). The chains are separated by a unit-cell length along the $c$ axis and are arranged parallel to each other forming layers parallel to the $a c$ plane of the unit cell. The layers are separated by a unit-cell length along the $b$ axis of the unit cell (Figure 1c). The structure of $\mathbf{I}$ is somewhat related to that of $\mathbf{I}$. Compound II can be described as being obtained by replacing the coordinating water molecules in $\mathbf{I}$ by oxygen atoms of one more bridging glycine molecule. Thus, in II there is one more glycine bridge between the metal atoms relative to I. Multipoint $\mathrm{N}-\mathrm{H} \ldots \mathrm{Cl}, \mathrm{N}-\mathrm{H} \ldots \mathrm{O}$, and $\mathrm{C}-\mathrm{H} \ldots \mathrm{Cl}$ hydrogen bonding stabilizes the structure of II as well. The $\mathrm{Mn}-\mathrm{O}$ and $\mathrm{Mn}-\mathrm{Cl}$ bond lengths lie in the range of 2.188(2)-2.201(2) $\AA$ (average $2.195 \AA$ ) and 2.526(1) $\AA$, respectively. The average $\mathrm{C}-\mathrm{O}, \mathrm{C}-\mathrm{C}$, and $\mathrm{C}-\mathrm{N}$ distances in the glycine unit are 1.256 , 1.514 , and $1.481 \mathrm{~A}^{\circ}$, respectively.

The temperature dependence of the magnetic susceptibility of II was recorded in the $T=5-300 \mathrm{~K}$ range. The material is paramagnetic and the linear fit to the inverse susceptibility data above $100 \mathrm{~K}$ gave a Curie-Weiss temperature of $-11 \mathrm{~K}$, indicating the presence of weak antiferromagnetic interactions. The effective moment at room temperature was $5.81 \mu_{\mathrm{B}}$ per atom, consistent with the value commonly observed for carboxylate-bridged high-spin $\mathrm{Mn}^{2+}$ ions. ${ }^{[8]}$

The asymmetric unit of the cadmium glycinate $\left[\mathrm{Cd}_{3} \mathrm{Cl}_{6}\left(\mathrm{CO}_{2} \mathrm{CH}_{2} \mathrm{NH}_{3}\right)_{4}\right]$ (III) contains 15 non-hydrogen atoms, with two $\mathrm{Cd}$ atoms of which one is in a special position with half occupancy. The two $\mathrm{Cd}$ atoms are in different coordination environments, $\mathrm{Cd} 1$ being surrounded by four doubly bridging chlorine atoms and two glycinate oxygen atoms in a trans fashion, and $\mathrm{Cd} 2$ being bonded to four bridging chlorine atoms and two oxygen atoms of a chelating glycine molecule in a cis fashion. There are two types of glycine molecules in III, both in the zwitterionic form. One of the glycine molecules bonds to $\mathrm{Cd} 1$ in a monodentate fashion through its carboxylate oxygen atom, whereas the other binds to $\mathrm{Cd} 2$ in a chelating fashion. The bridging chlorine atoms join the $\mathrm{Cd}$ centers to form chains with the glycine molecules dangling out of the chains and decorating them (Figure $2 \mathrm{a}$ ). $\mathrm{Cd} 2$ has a distorted octahedral coordination, with the $\mathrm{X}-\mathrm{Cd}-\mathrm{X}(\mathrm{X}=\mathrm{O}, \mathrm{Cl})$ angles varying from $53.4(2)$ to $158.84(6)^{\circ}$, rendering the chain wavelike. The chains are arranged parallel to each other forming layers (Figure 2b). The structure is stabilized by $\mathrm{N}-\mathrm{H} \ldots \mathrm{O}, \mathrm{N}-$ $\mathrm{H} \cdot . \mathrm{Cl}, \mathrm{C}-\mathrm{H} \cdots \mathrm{O}$ and $\mathrm{C}-\mathrm{H} \ldots \mathrm{Cl}$ hydrogen bonding. 

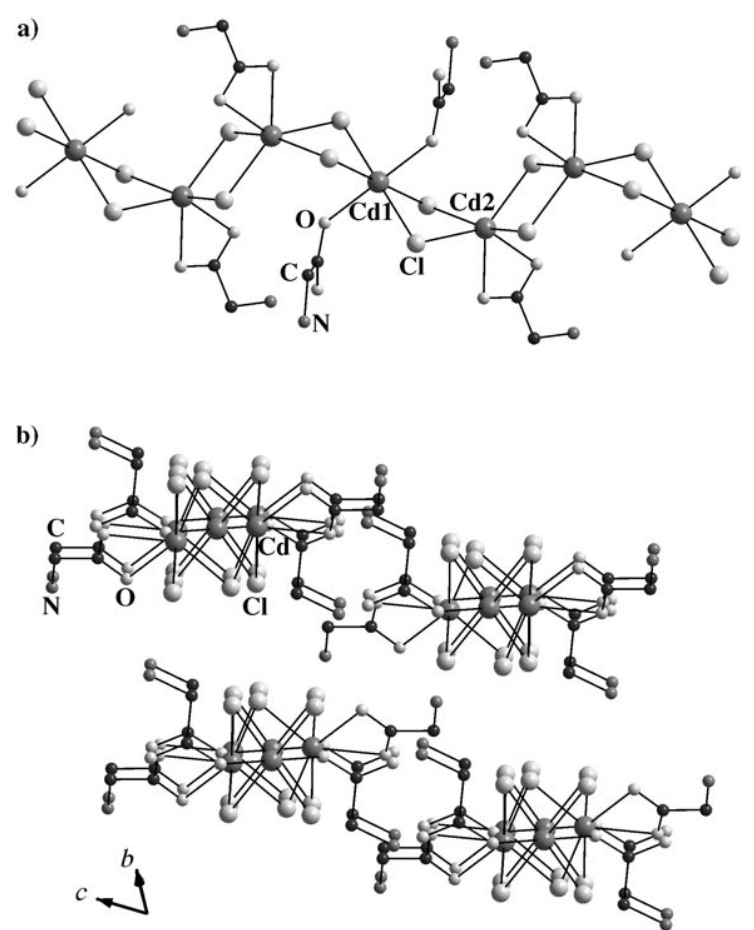

Figure 2. a) Chain structure of $\left[\mathrm{Cd}_{3} \mathrm{Cl}_{6}\left(\mathrm{CO}_{2} \mathrm{CH}_{2} \mathrm{NH}_{3}\right)_{4}\right]$ (III) formed by the bridging of the $\mathrm{Cd}$ centers by $\mathrm{Cl}$ atoms. Note the distorted octahedral environment around $\mathrm{Cd} 2$. b) Three-dimensional packing diagram of III viewed down the $a$ axis of the unit cell.

The $\mathrm{Cd} 1-\mathrm{O}$ and $\mathrm{Cd} 1-\mathrm{Cl}$ bond lengths are in the range of 2.299(5) and 2.586(2)-2.629(2) $\AA$ (average 2.608 $\AA$ ), respectively. The $\mathrm{Cd} 2-\mathrm{O}$ and $\mathrm{Cd} 2-\mathrm{Cl}$ bond lengths are in the range of 2.318(5)-2.534(5) $\AA$ (average $2.426 \AA$ ) and 2.569(2)-2.709(2) $\AA$ (average 2.614 $\AA$ ), respectively. The average $\mathrm{C}-\mathrm{O}, \mathrm{C}-\mathrm{C}$, and $\mathrm{C}-\mathrm{N}$ distances of the glycine molecule are $1.249,1.514$, and $1.484 \AA$, respectively.

We have obtained a one-dimensional compound, $\left[\mathrm{CdBr}_{2}-\right.$ $\left.\left(\mathrm{C}_{4} \mathrm{H}_{7} \mathrm{NO}\right)_{2}\right]$ (IV), on reacting $\mathrm{CdBr}_{2}$ with 4-aminobutyric acid under hydrothermal conditions in the presence of $\mathrm{HBr}$. Under these reactions conditions, 4-aminobutyric acid is transformed to cyclobutamide, which coordinates to the metal through the amide oxygen atom. The asymmetric unit of IV contains nine non-hydrogen atoms, all present in special positions with half occupancy. Each $\mathrm{Cd}$ atom is surrounded by three triply bridging bromine atoms and two doubly bridging bromine atoms, the octahedral environment around $\mathrm{Cd}$ being satisfied by bonding to the oxygen atoms of cyclobutamide. The $\mathrm{Cd}$ centers are connected by both doubly and triply bridging bromine atoms to form double chains parallel to the $b$ axis of the unit cell, the amide molecules protruding from the chains as shown in Figure 3a. These $\mathrm{Cd}-\mathrm{Br}$ double chains contain features of the hexagonal $\mathrm{CdBr}_{2}$ layers. This double chain in $\mathbf{I V}$ is similar to that found in $\mathrm{ABX}_{3}$ (in which $\mathrm{A}$ and $\mathrm{B}$ are cations and $\mathrm{X}$ is an anion) compounds, except that the terminal $\mathrm{X}$ position is occupied by the amide oxygen. ${ }^{[9]}$ The chains are arranged parallel to each other and are separated by half the unit-cell
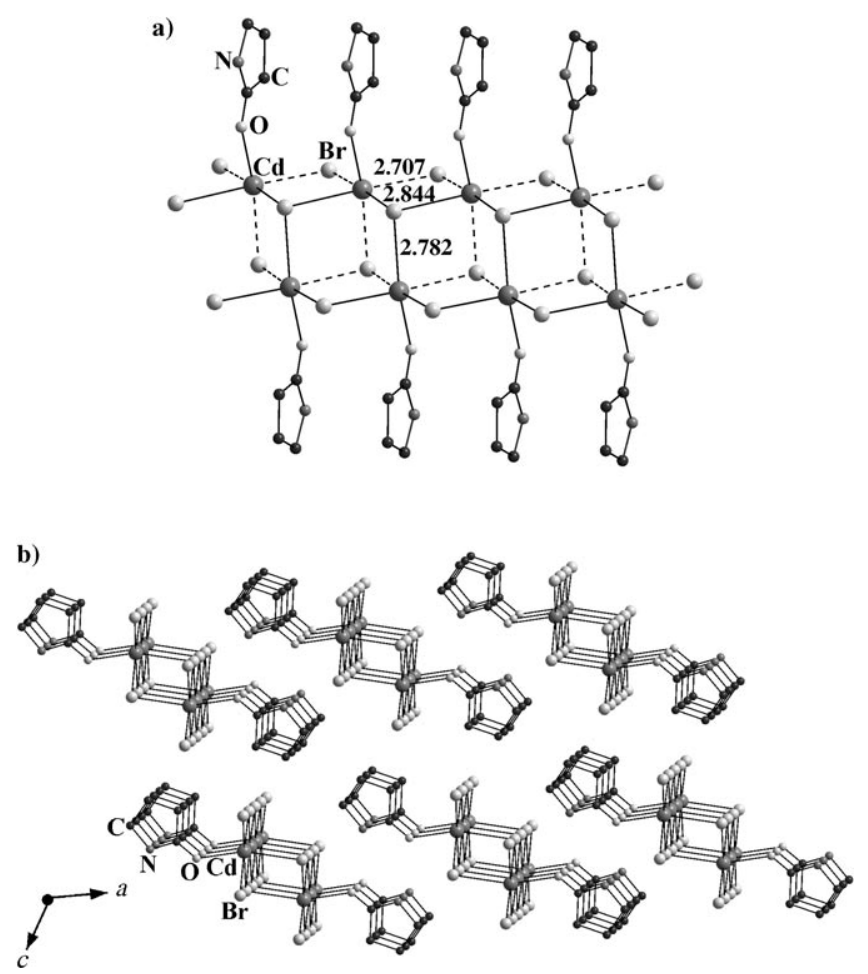

Figure 3. a) One-dimensional double-chain structure of $\left[\mathrm{CdBr}_{2}-\right.$ $\left(\mathrm{C}_{4} \mathrm{H}_{7} \mathrm{NO}\right)_{2}$ ] (IV) containing both doubly and triply bridging $\mathrm{Br}$ atoms. Note the amide molecules protruding out from the chains and decorating them. b) Three-dimensional packing diagram of IV viewed down the $b$ axis of the unit cell.

length along the $a$ axis to form layers parallel to the $a b$ plane of the unit cell. The layers are separated by a unit-cell length along the $c$ axis (Figure $3 b$ ). $\mathrm{N}-\mathrm{H}$... O hydrogen bonds between the amide groups of adjacent chains stabilize the structure. The $\mathrm{Cd}-\mathrm{O}$ and $\mathrm{Cd}-\mathrm{Br}$ bond lengths in $\mathbf{I V}$ are in the range of 2.292(6) and 2.707(1)-2.844(1) $\AA$ (average $2.793 \AA$ ), respectively. The longer $\mathrm{Cd}-\mathrm{Br}$ bond lengths of 2.782 and $2.844 \AA$ correspond to the $\mu_{3}-\mathrm{Br}$ atoms compared with the bond length of $2.707 \AA$ for the $\mu_{2}-\mathrm{Br}$ atoms. The average $\mathrm{C}-\mathrm{O}, \mathrm{C}-\mathrm{C}$, and $\mathrm{C}-\mathrm{N}$ distances of the amide molecule are $1.238,1.484$, and $1.392 \AA$, respectively. We have also prepared the chloro compound, $\left[\mathrm{CdCl}_{2}\left(\mathrm{C}_{4} \mathrm{H}_{7} \mathrm{NO}\right)_{2}\right]$, which is isostructural with $\mathbf{I V}$, by using $\mathrm{HCl}$ instead of $\mathrm{HBr}$ during the synthesis. It is noteworthy that in both III and IV, both prepared from $n$-butanol, the structural features of the cadmium halide are retained in the final product. A similar behavior has been observed in cadmium chlorooxalates. ${ }^{[10]}$

Layered structures: Glycine, in the zwitterionic form, forms a two-dimensional layered compound with manganese of the formula $\left[\mathrm{Mn}\left(\mathrm{H}_{2} \mathrm{O}\right)_{2}\left(\mathrm{CO}_{2} \mathrm{CH}_{2} \mathrm{NH}_{3}\right)_{2}\right] \mathrm{Br}_{2}(\mathbf{V})$. The asymmetric unit of $\mathbf{V}$ contains eight non-hydrogen atoms of which seven belong to the framework and one to an interstitial bromine atom. The Mn atom is in a special position with half occupancy and is octahedrally surrounded by four oxygen atoms of bridging glycine molecules and two water molecules in a trans fashion. The glycine molecule, present 
in the zwitterionic form, bridges the Mn centers to form layers with a $(4,4)$-net topology parallel to the $b c$ plane of the unit cell (Figure 4a). ${ }^{[9,11]}$ The water molecules and the amine end of the glycine molecules protrude out from the

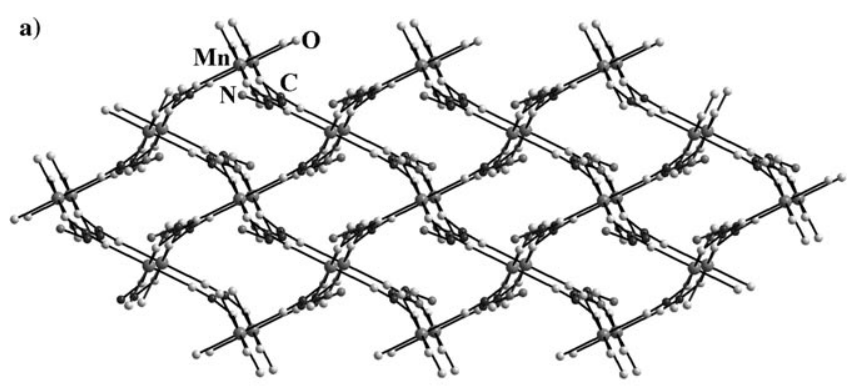

b)
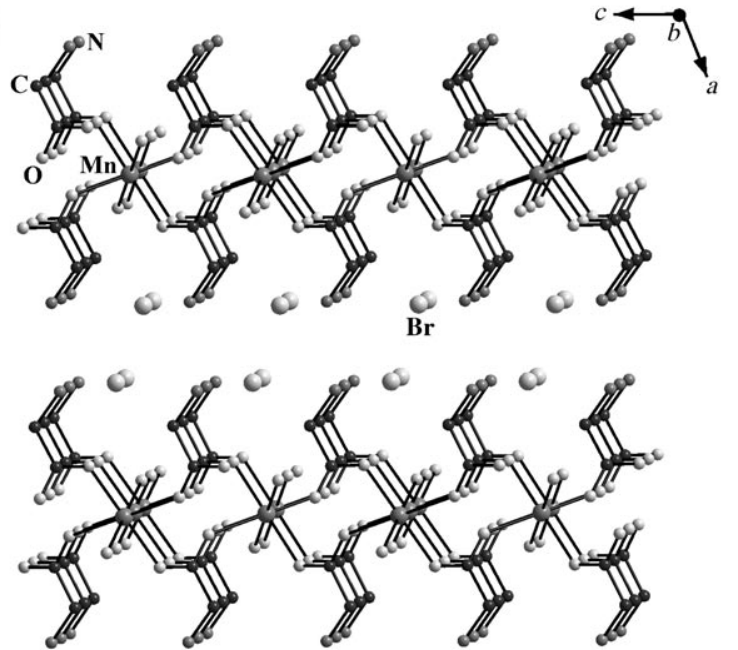

Figure 4. a) Top view of the two-dimensional rhombohedral grid structure of $\left[\mathrm{Mn}\left(\mathrm{H}_{2} \mathrm{O}\right)_{2}\left(\mathrm{CO}_{2} \mathrm{CH}_{2} \mathrm{NH}_{3}\right)_{2}\right] \mathrm{Br}_{2}(\mathbf{V})$. Note the presence of rhombic tunnels down the $a$ axis of the unit cell. b) Stacking of layers in three-dimensions with the bromide ions residing in the interlamellar region.

layer, forming hydrogen bonds with the bromine atoms present in the interlamellar region (Figure 4b). These cationic layers are stacked over one another in an AAA fashion and are separated by a unit-cell length along the $a$ axis. Such stacking gives rise to rhombic tunnels with an $\mathrm{Mn}-\mathrm{Mn}$ cross section of $5.4 \times 5.4 \AA$ down the $a$ axis of the unit cell. The long and short $\mathrm{Mn}-\mathrm{Mn}$ distances measured diagonally across the rhombic apertures (Figure 4a) are 8.992 and $6.057 \AA$, respectively. The structure is stabilized by $\mathrm{O}-\mathrm{H} \ldots \mathrm{O}$, $\mathrm{O}-\mathrm{H} \cdots \mathrm{Br}, \mathrm{N}-\mathrm{H} \cdots \mathrm{Br}$, and $\mathrm{C}-\mathrm{H} \cdots \mathrm{O}$ hydrogen bonds. The $\mathrm{Mn}-\mathrm{O}$ bond lengths lie in the range of 2.170(4)-2.182(3) $\AA$ (average $2.175 \AA$ ). The average $\mathrm{C}-\mathrm{O}, \mathrm{C}-\mathrm{C}$, and $\mathrm{C}-\mathrm{N}$ distances of the glycine molecule are $1.257,1.503$, and $1.477 \AA$, respectively. We have also obtained layered glycinates of $\mathrm{Co}$ and $\mathrm{Ni}$ isostructural with $\mathbf{V}$.

The temperature dependence of the magnetic susceptibility of $\mathbf{V}$ was recorded in the $T=5-300 \mathrm{~K}$ range. The compound is paramagnetic and the linear fit to the inverse susceptibility data above $100 \mathrm{~K}$ gives a near zero value for the
Curie-Weiss temperature. The effective moment at room temperature is $5.90 \mu_{\mathrm{B}}$ per atom, as expected of carboxylatebridged high-spin $\mathrm{Mn}^{2+}$ centers. ${ }^{[8]}$

The reaction of 6-aminocaproic acid with cadmium and copper salts in alkaline medium at room temperature gave layered compounds. Addition of a mineral acid to the reaction mixture to make the $\mathrm{pH}$ acidic was detrimental in forming these compounds. The asymmetric unit of the two-dimensional compound with cadmium, [Cd$\left.\left\{\mathrm{CO}_{2}\left(\mathrm{CH}_{2}\right)_{5} \mathrm{NH}_{2}\right\}_{2}\right] \cdot 2 \mathrm{H}_{2} \mathrm{O}$ (VI), contains 21 non-hydrogen atoms of which 19 belong to the framework and two to the interstitial water molecules. The $\mathrm{Cd}$ atom is octahedrally surrounded by four oxygen atoms and two nitrogen atoms of 6-aminocaproic acid, which is in the deprotonated form. The molecule bridges the Cd centers through its carboxylate end to form $\mathrm{Cd}$-carboxylate-Cd chains parallel to the $b$ axis of the unit cell. The chains become cross-linked at the amine end of the molecule to form layers as shown in Figure 5a. Such a connectivity gives rise to empty hydrophobic tunnels running across the layers. These layers are stacked over one another with the water molecules residing in the interlamellar region, forming $\mathrm{O}-\mathrm{H} \cdots \mathrm{O}$ and $\mathrm{N}-\mathrm{H} \cdots \mathrm{O}$ hydrogen bonds (Figure $5 \mathrm{~b}$ ). The $\mathrm{Cd}-\mathrm{O}$ and $\mathrm{Cd}-\mathrm{N}$ bond lengths in VI are in the range of 2.348(6)-2.377(6) $\AA$ (average

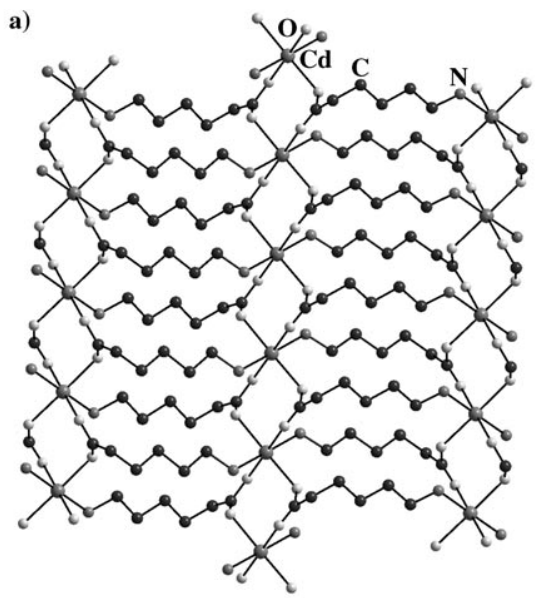

b)

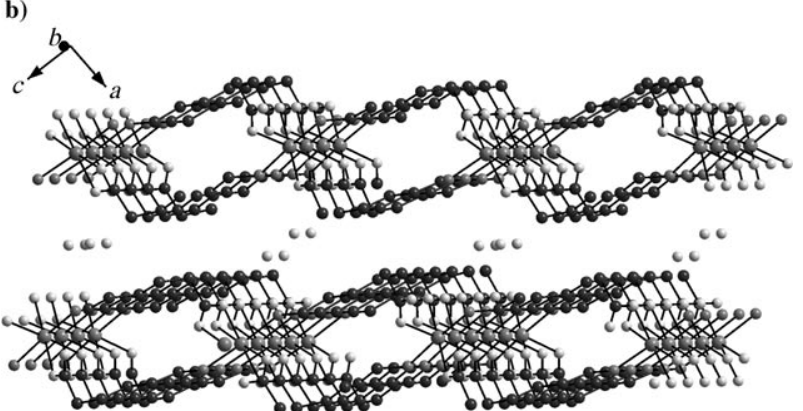

Figure 5. a) Two-dimensional layered structure of [Cd$\left.\left\{\mathrm{CO}_{2}\left(\mathrm{CH}_{2}\right)_{5} \mathrm{NH}_{2}\right\}_{2}\right] \cdot 2 \mathrm{H}_{2} \mathrm{O}$ (VI) formed by the cross-linking of the Cd-carboxylate- $\mathrm{Cd}$ chains by the amine end of the aminocarboxylate molecule. b) Three-dimensional packing diagram of VI with the water molecules residing in the interlamellar region. Note the presence of hydrophobic channels running through the layers. 
$2.36 \AA$ ) and 2.273(7)-2.286(8) $\AA$ (average $2.28 \AA$ ), respectively. The average $\mathrm{C}-\mathrm{O}, \mathrm{C}-\mathrm{C}$, and $\mathrm{C}-\mathrm{N}$ distances of the 6aminocaproic acid moiety are $1.26,1.519$, and $1.487 \AA$, respectively.

6-Aminocaproic acid forms a neutral compound with copper, $\left[\mathrm{Cu}\left\{\mathrm{CO}_{2}\left(\mathrm{CH}_{2}\right)_{5} \mathrm{NH}_{2}\right\}_{2}\right] \cdot 2 \mathrm{H}_{2} \mathrm{O}$ (VII), with a two-dimensional architecture possessing large voids. The asymmetric unit of VII contains 11 non-hydrogen atoms of which ten belong to the framework and one to the interstitial water molecule. The $\mathrm{Cu}$ atom is in a special position with half occupancy and is surrounded by two oxygen atoms and two nitrogen atoms of 6-aminocaproic acid in a square-planar arrangement with average $\mathrm{Cu}-\mathrm{O} / \mathrm{N}$ bond lengths of 1.974 (for O) and $1.990 \AA$ (for $\mathrm{N}$ ). The $\mathrm{Cu}$ atom is Jahn-Teller distorted, the octahedral environment around copper being completed by bonding to another carboxylate oxygen atom of the 6-aminocaproic acid molecule with a $\mathrm{Cu}-\mathrm{O}$ bond length of $2.764 \AA$. Thus, the anionic 6-aminocaproic acid molecule bridges the $\mathrm{Cu}$ centers at one end through its carboxylate group and the nitrogen at another end to form layers with a (4,4)-net topology. ${ }^{[9,11]}$ The layers are stacked over one another in an AAA fashion resulting in the formation of rhombohedral tunnels with dimensions of $11.487 \times 11.487 \AA$ measured from $\mathrm{Cu}$ to $\mathrm{Cu}$ down the $c$ axis of the unit cell (Figure 6). The long and short $\mathrm{Cu}-\mathrm{Cu}$ distances across the

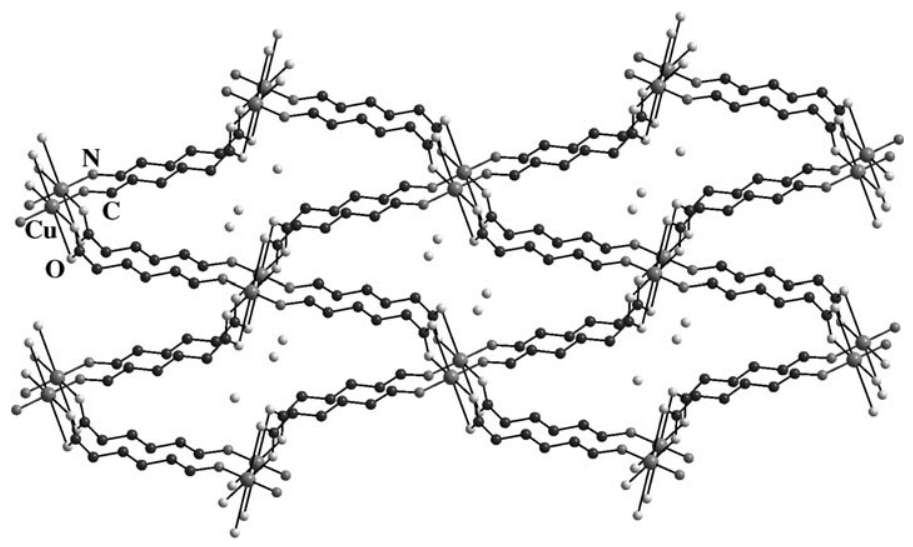

Figure 6. Top view of the two-dimensional neutral layers of $[\mathrm{Cu}$ $\left.\left\{\mathrm{CO}_{2}\left(\mathrm{CH}_{2}\right)_{5} \mathrm{NH}_{2}\right\}_{2}\right] \cdot 2 \mathrm{H}_{2} \mathrm{O}$ (VII) with large rhombohedral tunnels running down the $c$ axis of the unit cell. Water molecules reside in the tunnels.

tunnel aperture are 20.064 and $11.487 \AA$, respectively. Interstitial water molecules reside in the tunnels, forming $\mathrm{O}^{-}$ $\mathrm{H}$... O hydrogen bonds with the framework oxygen atoms. The average $\mathrm{C}-\mathrm{O}, \mathrm{C}-\mathrm{C}$, and $\mathrm{C}-\mathrm{N}$ distances of the 6-aminocaproic acid in VII are $1.256,1.515$, and $1.480 \AA$, respectively. It is interesting that the apical $\mathrm{Cu}-\mathrm{O}$ bond length of $2.764 \AA$ in VII is longer that that commonly observed in copper coordination polymers, indicating the presence of very weak bonding interactions and thus making it accessible for host-guest interactions. Guest binding sites in porous metal-organic frameworks are important for the development of functional properties. ${ }^{[12]}$

Compound VII has voids occupied by guest water molecules. Its porous nature was examined by heating the sample at $180^{\circ} \mathrm{C}$ for $2 \mathrm{~h}$ and then allowing it to cool to room temperature. Thermogravimetric analysis and the powder X-ray diffraction patterns showed that VII loses the water molecules just above $100^{\circ} \mathrm{C}$, and transforms to another crystalline porous material, as indicated by the low-angle line in the powder diffraction pattern (Figure 7). The dehydrated framework, however, does not appear to revert back to the original framework structure of VII upon exposure to water vapor.

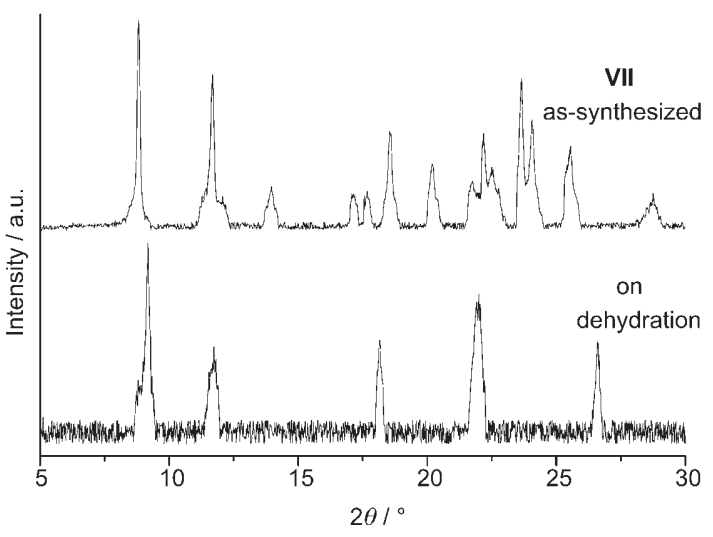

Figure 7. Powder XRD patterns of VII and its dehydrated form.

The temperature dependence of the magnetic susceptibility of VII was recorded in the $T=5-300 \mathrm{~K}$ range. The compound is paramagnetic and the linear fit to the inverse susceptibility data above $100 \mathrm{~K}$ gives a near zero value for the Curie-Weiss temperature. The effective moment at room temperature is $1.77 \mu_{\mathrm{B}}$ per atom, as expected for one unpaired electron.

\section{Conclusion}

In summary, we have obtained both one-dimensional chain and two-dimensional layered metal glycinate coordination polymers by carrying out hydrothermal reactions of glycine with metal salts in an acidic medium. At acidic $\mathrm{pH}$, the aminocarboxylic acid binds to the metal only through its carboxyl end, whereas at neutral and alkaline $\mathrm{pH}$, the amino acid can coordinate with the metal through the amino nitrogen atom as well as through the carboxyl oxygen atoms. ${ }^{[4-7,13]}$ Thus, 6-aminocaproic acid yields layered structures at neutral or alkaline $\mathrm{pH}$, in which the two ends of the molecule are bonded to metal atoms at either end. The presence of large apertures in one of the layered structures with potential sorption properties is noteworthy. It should be possible to synthesize a variety of coordination polymers by employing various amino acids in different media. 


\section{Experimental Section}

\section{Synthesis}

$\left[\mathrm{CoCl}_{2}\left(\mathrm{H}_{2} \mathrm{O}\right)_{2}\left(\mathrm{CO}_{2} \mathrm{CH}_{2} \mathbf{N H}_{3}\right)\right]$ (I): $\mathrm{CoCO}_{3}(100 \mathrm{mg})$ was dispersed in tetrahydrofuran $(2 \mathrm{~mL})$, to which concentrated hydrochloric acid $(0.15 \mathrm{~mL})$ was added dropwise to generate $\mathrm{CoCl}_{2}$ in situ. This was followed by the addition of glycine $(126.2 \mathrm{mg})$ and the reaction mixture was stirred for $30 \mathrm{~min}$. The final mixture, with a $\mathrm{CoCl}_{2} /$ glycine ratio of $1: 2$, was transferred to a $7 \mathrm{~mL}$ PTFE-lined (PTFE = polytetrafluoroethylene) acid digestion bomb and heated at $150^{\circ} \mathrm{C}$ for $48 \mathrm{~h}$. The product, comprising pink crystals, was vacuum filtered and washed with ethanol.

[ $\mathbf{M n C l}_{2}\left(\mathrm{CO}_{2} \mathrm{CH}_{2} \mathrm{NH}_{3}\right)_{2}$ ] (II): A procedure similar to that described for I was employed for the synthesis of II, with $\mathrm{MnCl}_{2} \cdot 6 \mathrm{H}_{2} \mathrm{O}$ as the source of manganese.

[ $\left.\mathrm{Cd}_{3} \mathrm{Cl}_{\mathbf{6}}\left(\mathrm{CO}_{\mathbf{2}} \mathrm{CH}_{2} \mathbf{N H}_{3}\right)_{4}\right]$ (III): $\mathrm{CdCl}_{2} \cdot 6 \mathrm{H}_{2} \mathrm{O}(100 \mathrm{mg})$ was dispersed in $n$ butanol $(3 \mathrm{~mL})$, to which glycine $(149.2 \mathrm{mg})$ was added. The resultant reaction mixture, with $\mathrm{CdCl}_{2} /$ glycine ratio of $1: 2$, was stirred for $30 \mathrm{~min}$ and then transferred to a $7 \mathrm{~mL}$ PTFE-lined acid digestion bomb and heated at $100^{\circ} \mathrm{C}$ for $48 \mathrm{~h}$. The product, comprising colorless crystals, was vacuum filtered and washed with ethanol.

[C $\left.\mathbf{C d B r}_{2}\left(\mathbf{C}_{4} \mathbf{H}_{7} \mathbf{N O}\right)_{2}\right]$ (IV): $\mathrm{CdO}(75 \mathrm{mg})$ was dispersed in $n$-butanol $(2 \mathrm{~mL})$, to which concentrated $\mathrm{HBr}(0.13 \mathrm{~mL})$ was added to generate $\mathrm{CdBr}_{2}$. To this solution, 4-aminobutyric acid $(240.9 \mathrm{mg})$ was added and the reaction mixture was stirred for $30 \mathrm{~min}$. The mixture, with $\mathrm{CdBr}_{2}$ and 4-aminobutyric acid in the ratio $1: 2$, was transferred to a $7 \mathrm{~mL}$ PTFElined acid digestion bomb and heated at $150^{\circ} \mathrm{C}$ for $48 \mathrm{~h}$. The product, comprising colorless crystals, was vacuum filtered and washed with ethanol. The chloro analogue of IV was obtained by a similar procedure by using concentrated $\mathrm{HCl}$ instead of $\mathrm{HBr}$.
$\left[\mathbf{M n}\left(\mathbf{H}_{2} \mathbf{O}\right)_{2}\left(\mathbf{C O}_{2} \mathbf{C H}_{2} \mathbf{N H}_{3}\right)_{2}\right] \mathbf{B r}_{2}(\mathbf{V}): \mathrm{MnCO}_{3}(100 \mathrm{mg})$ was dispersed in tetrahydrofuran $(2 \mathrm{~mL})$, to which concentrated $\mathrm{HBr}(0.2 \mathrm{~mL})$ was added to generate $\mathrm{MnBr}_{2}$ in situ. To this solution, glycine $(130.6 \mathrm{mg})$ was added and the reaction mixture was stirred for $30 \mathrm{~min}$. The mixture of $\mathrm{MnBr}_{2}$ and glycine in the ratio of 1:2 was transferred to a $7 \mathrm{~mL}$ PTFE-lined acid digestion bomb and heated at $150^{\circ} \mathrm{C}$ for $48 \mathrm{~h}$. The product, comprising colorless crystals, was vacuum filtered and washed with ethanol. The cobalt and nickel analogues were prepared by employing a similar procedure, using $\mathrm{CoCO}_{3}$ and $2 \mathrm{NiCO}_{3} \cdot 3 \mathrm{Ni}(\mathrm{OH})_{2} \cdot 4 \mathrm{H}_{2} \mathrm{O}$ as the sources for $\mathrm{Co}$ and $\mathrm{Ni}$, respectively.

[Cd $\left.\left\{\mathrm{CO}_{2}\left(\mathrm{CH}_{2}\right)_{5} \mathbf{N H}_{2}\right\}_{2}\right] \cdot \mathbf{2} \mathrm{H}_{2} \mathrm{O}$ (VI): $\mathrm{CdCl}_{2} \cdot 6 \mathrm{H}_{2} \mathrm{O}(100 \mathrm{mg})$ and 6-aminocaproic acid $(130.3 \mathrm{mg})$ were dissolved in water $(2 \mathrm{~mL})$, to which a solution of piperazine $(85.5 \mathrm{mg})$ in toluene $(2 \mathrm{~mL})$ was layered, and kept at room temperature. After $24 \mathrm{~h}$, colorless crystals of VI were obtained. The crystals were vacuum filtered and washed with ethanol.

$\left[\mathbf{C u}\left\{\mathrm{CO}_{2}\left(\mathrm{CH}_{2}\right)_{\mathbf{5}} \mathbf{N H}_{2}\right\}_{2}\right] \cdot \mathbf{2} \mathrm{H}_{\mathbf{2}} \mathrm{O}$ (VII): 6-Aminocaproic acid (153.9 mg) was added to a ammoniacal solution of $\mathrm{CuCl}_{2} \cdot 6 \mathrm{H}_{2} \mathrm{O}(100 \mathrm{mg})$ in water $(2 \mathrm{~mL})$ and the deep blue solution was kept at room temperature for $48 \mathrm{~h}$. The obtained blue crystals of VII were vacuum filtered and washed with water.

Characterization: The yields of the various compounds generally exceeded $80 \%$. The compounds were characterized by powder X-ray diffraction (XRD) analysis, which indicated that the products were new material and monophasic, the patterns being consistent with those generated from single-crystal X-ray diffraction analysis. Elemental analyses of I-VII were satisfactory.

Elemental analysis calcd (\%) for I: C 9.97, N 5.81, H 3.74; found: C 9.88, N 5.99, H 3.78; elemental analysis calcd (\%) for II: C 17.4, N 10.15, H 3.63; found: C 17.53, N 10.29, H 3.70; elemental analysis calcd (\%) for III: C 11.3, N 6.59, H 2.35; found: C 11.18, N 6.69, H 2.43; elemental analysis calcd (\%) for IV: C 21.71, N 6.33, H 3.17; found: C 21.82, N

Table 1. Crystal data and structure refinement parameters for compounds $\mathbf{I}-\mathbf{I V} \mathbf{.}^{[\mathrm{a}]}$

\begin{tabular}{|c|c|c|c|c|}
\hline & $\mathbf{I}$ & II & III & $\mathbf{I} \mathbf{V}^{[\mathrm{b}]}$ \\
\hline $\begin{array}{l}\text { formula } \\
\text { crystal system }\end{array}$ & $\begin{array}{l}\mathrm{CoCl}_{2} \mathrm{C}_{2} \mathrm{H}_{9} \mathrm{NO}_{4} \\
\text { monoclinic }\end{array}$ & $\begin{array}{l}\mathrm{MnCl}_{2} \mathrm{C}_{4} \mathrm{H}_{10} \mathrm{~N}_{2} \mathrm{O}_{4} \\
\text { triclinic }\end{array}$ & $\begin{array}{l}\mathrm{Cd}_{3} \mathrm{Cl}_{6} \mathrm{C}_{8} \mathrm{H}_{20} \mathrm{~N}_{4} \mathrm{O}_{8} \\
\text { triclinic }\end{array}$ & $\begin{array}{l}\mathrm{CdBr}_{2} \mathrm{C}_{4} \mathrm{H}_{7} \mathrm{NO} \\
\text { monoclinic }\end{array}$ \\
\hline space group & $P 2(1) / n$ & $P \overline{1}$ & $P \overline{1}$ & $C 2 / m$ \\
\hline crystal size [mm] & $0.3 \times 0.23 \times 0.25$ & $0.21 \times 0.23 \times 0.16$ & $0.25 \times 0.27 \times 0.25$ & $0.35 \times 0.18 \times 0.2$ \\
\hline$a[\AA]$ & $6.3759(5)$ & $4.9751(2)$ & $8.7588(11)$ & $20.046(3)$ \\
\hline$b[\AA]$ & $15.8733(12)$ & $6.6025(4)$ & $8.9314(11)$ & $4.0553(6)$ \\
\hline$c[\AA]$ & $7.7530(6)$ & $7.9309(5)$ & $9.0376(12)$ & $11.243(2)$ \\
\hline$\beta\left[^{\circ}\right]$ & $97.604(2)$ & $92.850(3)$ & $61.848(2)$ & $119.822(2)$ \\
\hline$\gamma\left[^{\circ}\right]$ & 90.0 & $107.055(2)$ & $66.250(2)$ & 90.0 \\
\hline$V\left[\AA^{3}\right]$ & $777.75(10)$ & $236.64(2)$ & $557.25(12)$ & $793.0(2)$ \\
\hline$Z$ & 4 & 1 & 1 & 4 \\
\hline fw & 240.93 & 275.98 & 850.22 & 357.32 \\
\hline$\rho_{\text {calcd }}\left[\mathrm{g} \mathrm{cm}^{-3}\right]$ & 2.058 & 1.937 & 2.533 & 2.993 \\
\hline$\lambda[\AA]$ & 0.71073 & 0.71073 & 0.71073 & 0.71073 \\
\hline$\mu\left[\mathrm{mm}^{-1}\right)$ & 2.851 & 1.942 & 3.598 & 12.753 \\
\hline total data & 3267 & 1009 & 2388 & 1676 \\
\hline \multirow[t]{3}{*}{ limiting indices } & $-7 \leq h \leq 7$ & $-4 \leq h \leq 5$ & $-9 \leq h \leq 9$ & $-22 \leq h \leq 19$ \\
\hline & $-8 \leq k \leq 17$ & $-7 \leq k \leq 7$ & $-9 \leq k \leq 9$ & $-4 \leq k \leq 4$ \\
\hline & $-8 \leq l \leq 8$ & $-7 \leq l \leq 8$ & $-10 \leq l \leq 6$ & $-12 \leq \bar{l} \leq 12$ \\
\hline unique data & $112 \overline{3}$ & $678-$ & 1592 & 669 \\
\hline observed data $[I>2 \sigma(I)]$ & 979 & 613 & 1266 & 599 \\
\hline$R_{\text {int }}$ & 0.0272 & 0.0140 & 0.0253 & 0.0360 \\
\hline$R$ indexes $[I>2 \sigma(I)]$ & $R_{1}=0.0259, w R_{2}=0.0658$ & $R_{1}=0.0270, w R_{2}=0.0689$ & $R_{1}=0.0324, w R_{2}=0.0714$ & $R_{1}=0.0442, w R_{2}=0.1160$ \\
\hline$R$ (all data) & $R_{1}=0.0301, w R_{2}=0.0679$ & $R_{1}=0.0299, w R_{2}=0.0702$ & $R_{1}=0.0467, w R_{2}=0.0771$ & $R_{1}=0.0476, w R_{2}=0.01181$ \\
\hline GOF & 1.063 & 1.021 & 0.977 & 1.060 \\
\hline no. of variables & 107 & 81 & 133 & 55 \\
\hline largest diff. map peak and hole $\left[\mathrm{e} \AA^{-3}\right]$ & 0.309 and -0.319 & 0.291 and -0.465 & 0.832 and -0.831 & 0.743 and -1.870 \\
\hline
\end{tabular}

[a] $R_{1}=\Sigma|| F_{\mathrm{o}}|-| F_{\mathrm{c}}|| / \Sigma\left|F_{\mathrm{o}}\right| ; w R_{2}=\left\{\Sigma\left[w\left(F_{\mathrm{o}}^{2}-F_{\mathrm{c}}^{2}\right)^{2}\right] / \Sigma\left[w\left(F_{\mathrm{o}}^{2}\right)^{2}\right]\right\}^{1 / 2}$, for which $w=1 /\left[\sigma^{2} F_{\mathrm{o}}^{2}+(a P)^{2}+b P\right] ; P=\left(F_{\mathrm{o}}^{2}+2 F_{\mathrm{c}}^{2}\right) / 3 ; a=0.0338$ and $b=0.7110$ for $\mathbf{I} ; a=$ 0.0524 and $b=0$ for II; $a=0.0362$ and $b=0$ for III; $a=0.0839$ and $b=0$ for IV. [b] The unit-cell dimensions of the isostructural chloro compound are $a=$ $19.6886, b=3.8917, c=10.8926 \AA$; $\beta=119.977^{\circ}$. 
6.41, H 3.05; elemental analysis calcd (\%) for V: C 12.00, N 7.00, H 3.49; found: C 11.95, N 7.07, H 3.55; elemental analysis calcd (\%) for VI: C 32.26, N 6.86, H 6.86; found: C 32.05, N 7.03, H 6.91; elemental analysis calcd (\%) for VII: C 40.05, N 7.79, H 7.79; found: C 39.87, N 7.82, H 7.71

Single-crystal structure determination: A suitable single crystal of each compound (I-VII) was carefully selected under a polarizing microscope and glued at the tip of a thin glass fiber with cyanoacrylate (super glue) adhesive. Single-crystal structure determination by X-ray diffraction analysis was performed on a Siemens Smart-CCD diffractometer equipped with a normal focus, $2.4 \mathrm{~kW}$ sealed-tube $\mathrm{X}$-ray source $\left(\mathrm{Mo}_{\mathrm{K} \alpha}\right.$ radiation, $\lambda=0.71073 \AA$ ) operating at $40 \mathrm{kV}$ and $40 \mathrm{~mA}$. A hemisphere of intensity data was collected at room temperature with $\omega$ space scans (width of $0.30^{\circ}$ and exposure time of $10 \mathrm{~s}$ per frame). Pertinent experimental details for the structure determination of compounds I-IV and V-VII are presented in Tables 1 and 2, respectively.

The structures were solved by direct methods by using the SHELXS-86 program, ${ }^{[14]}$ which readily established the heavy-atom position $(\mathrm{Co}, \mathrm{Mn}$, $\mathrm{Cd}, \mathrm{Cu}, \mathrm{Cl}, \mathrm{Br})$ and facilitated the identification of the light atoms $(\mathrm{O}, \mathrm{N}$, $\mathrm{C}, \mathrm{H}$ ) from difference Fourier maps. An empirical absorption correction based on symmetry-equivalent reflections was applied by using the SADABS program. ${ }^{[15]}$ All the hydrogen positions were initially located in the difference Fourier maps and the hydrogen atoms were placed geometrically and held in the riding mode for the final refinement. The last cycle of refinement included atomic positions for all the atoms, anisotropic thermal parameters for all the non-hydrogen atoms, and isotropic thermal parameters for all the hydrogen atoms. Full-matrix least-squares structure refinement against $\left|\mathrm{F}^{2}\right|$ was carried out (for compounds I-VII) by using the SHELXTL-PLUS package of programs. ${ }^{[16]}$ CCDC-279389
(I), -279390 (II), -279391 (III), -279392 (IV), -279393 (V), -279394 (VI), and -279395 (VII) contain the supplementary crystallographic data for this paper. These data can be obtained free of charge from the Cambridge Crystallographic Data Centre via www.ccdc.cam.ac.uk/data request/cif

\section{Acknowledgements}

The authors thank the Department of Science and Technology and the Defence Research and Development Organization (DRDO, India) for research support, and Dr. Sundaresan for help with magnetic measurements. M.D. thanks the Council of Scientific and Industrial Research (CSIR, India) for the award of a Senior Research Fellowship.

[1] a) D. W. Breck, Zeolite Molecular Sieves, Wiley, New York, 1974; b) W. M. Meier, D. H. Oslen, C. Baerlocher, Atlas of Zeolite Structure Types, Elsevier, London, 1996.

[2] A. K. Cheetham, G. Férey, T. Loiseau, Angew. Chem. 1999, 111, 3466; Angew. Chem. Int. Ed. 1999, 38, 3268.

[3] a) C. N. R. Rao, S. Natarajan, R. Vaidhyanathan, Angew. Chem. 2004, 116, 1490; Angew. Chem. Int. Ed. 2004, 43, 1466; b) O. M Yaghi, M. O'Keefe, N. W. Ockwig, H. K. Chae, M. Eddaoudi, J. Kim, Nature 2003, 423, 705.

[4] a) H. C. Freeman, M. R. Snow, Acta Crystallogr. 1964, 17, 1463; b) J. M. Newman, C. A. Bear, T. W. Hambley, H. C. Freeman, Acta Crystallogr. Sect. C 1990, 46, 44.

[5] a) J.-J. Zhang, S.-Q. Xia, T.-L. Sheng, S.-M. Hu, G. Leibeling, F. Meyer, X.-T. Wu, S.-C. Xiang, R.B. Fu, Chem. Commun. 2004 1186; b) H. An, Y. Guo, Y. Li, E. Wang, J. Lu, L. Xu, C. Hu, Inorg Chem. Commun. 2004, 7, 521 .

[6] R. Wang, H. Liu, M. D. Carducci, T. Jin, C. Zheng, Z. Zheng, Inorg. Chem. 2001, 40, 2743.

[7] N. Mercier, A. Riou, Chem. Commun. 2004, 844

[8] a) S. Durot, C. Policar, G. Pelosi, F. Bisceglie, T. Mallah, J.-P. Mahy, Inorg. Chem. 2003, 42, 8072; b) C. Policar, F. Lambert, M. Cesario, I. Morgenstern-Badarau, Eur. J. Inorg. Chem. 1999, 12, 2201.

[9] A. F. Wells, Structural Inorganic Chemistry, 5th ed., Oxford Press, $\mathbf{1 9 9 5}$, p. 450 , and references therein.

[10] R. Vaidhyanathan, S. Natarajan, C. N. R. Rao, Eur. J. Inorg. Chem 2003, 9, 1675 .

[11] a) M. O'Keeffe, B. G. Hyde, Philos. Trans. R. Soc. London Ser A 1980, 295, 553; b) S. R. Batten, R. Robson, Angew. Chem. 1998, 110, 1558; Angew. Chem. Int. Ed. 1998, 37, 1460 .

[12] a) O. M. Yaghi, C. E. Davis, G. Li, H. Li, J. Am. Chem. Soc. 1997, 119, 2861; b) T. M. Reineke, M. Eddaoudi, M. Fehr, D. Kelley, O. M. Yaghi, J. Am. Chem. Soc. 1999, 121, 1651; c) B. Chen, M Eddaoudi, T. M. Reinekke, J. Kampf, M. O'Keeffe, O. M. 
Yaghi, J. Am. Chem. Soc. 2000, 122, 11559.

[13] M. Dan, J. Mol. Struct. 2004, 706, 127.

[14] a) G. M. Sheldrick, SHELXS-86: Program for Crystal Structure Determination, University of Göttingen, Göttingen, Germany, 1986. b) G. M. Sheldrick, Acta Crystallogr. Sect. A 1990, 46, 467.

[15] G. M. Sheldrick, SADABS: Siemens Area Detector Absorption Correction Program, University of Göttingen, Göttingen, Germany, 1994
[16] G. M. Sheldrick, SHELXS-93: Program for Crystal Structure Solution and Refinement, University of Göttingen, Göttingen, Germany, 1993.

Received: July 30, 2005 Published online: October 12, 2005 